\title{
Die gesprek tussen AB du Toit en EP Sanders oor Paulus en die Palestynse Judaïsme: Die pad vorentoe
}

\author{
PF Craffert \\ Universiteit van Suid-Afrika
}

\begin{abstract}
The debate between $\mathrm{AB}$ du Toit and EP Sanders on Paul and Palestinian Judaism: The road ahead

The aim of the article is to analyse the underlying structure of the critical reaction of AB du Toit against EP Sanders's Pauline interpretation. It is shown that Du Toit's criticism of Sanders rests on his identification of Paul's opponents and their theology in Romans 4. This is questioned because of the dubious grounds on which his argument rests: the antithesis which is interpreted as polemical and the use of mirror reading. Secondly the underlying structures of their arguments are analysed. From this it becomes clear that there are hermeneutical and methodological differences between them which prevents Du Toit to do justice to Sanders's interpretation. Lastly it is suggested that a movement away from a strictly 'theological approach' to one which also takes the social context seriously, may be of much help in understanding what the historical Paul was saying.
\end{abstract}

In 'n onlangs gepubliseerde artikel in hierdie tydskrif het AB du Toit (1988: 71-80) in gesprek getree met EP Sanders oor laasgenoemde se Paulusinterpretasie. Wat Du Toit 'n gepreksbydrae noem, wil ek graag sien as 'n uitnodiging tot verdere gesprek. Hy merk tereg op dat die verskyning van Sanders se werke van die belangrikste bydraes is ten opsigte van die Paulusnavorsing, en hopelik sal iets van die debat ook in ons land ontwikkel en verdere navorsing stimuleer. Daarom dat ek die gesprek met Sanders en veral met Du Toit opneem in 'n poging om die gesprek 
voort te sit. Ek sal poog om die onderliggende struktuur van Du Toit se bydrae weer te gee en sodoende enkele kritiese vrae stel oor sy deel van die gesprek. Dit het ten doel om in te pas in die breë debat oor Sanders se interpretasie.

Du Toit gebruik een perikoop, Rom 4: 13-25, as uitgangspunt om enkele (kritiese) vrae aan Sanders te stel, veral ten opsigte van die probleem van geregtigheid deur die wet of geregtigheid deur die geloof. Die hoofklem val op Sanders se tese wat beweer dat die tradisionele navorsing Paulus sowel as die eerste-eeuse Judaïsme verkeerd verstaan het. Du Toit se vrae aan Sanders is daarop gerig om aan te toon dat Sanders vir beide Paulus en die Palestynse Judaïsme verkeerd verstaan het.

\section{ROMEINE 4: 'N POLEMIEK TEEN OPPONENTE?}

Die onderliggende logika waarop die hele betoog gebou is, sien ongeveer soos volg daaruit: In die breë struktuur van Rom 3: 21-4: 25 is daar talle antiteses en dit 'stellt jedoch den polemischen Character dieses Abschnitts ganz klar heraus' (Du Toit 1988: 72). Omdat dit 'n polemiek is, volg dit dat 'Paulus setzt sich ... mit der jüdischen Position auseinander' (Du Toit 1988: 74). Dit verseker 'dass wir, mit gebotener Vorsicht, doch gewisse Schlüsse über die Identität und die Überzeugungen der Gegner ziehen können und dürfen' (Du Toit 1988: 73). Hierdie basis word dan gebruik om die Joodse soteriologie waarteen Paulus dit het, te konstrueer sodat Sanders se teses daaraan getoets kan word.

Dit mag op die oog af onskuldig lyk om van 'n polemiek te praat, maar juis dit is die fundamentele veronderstelling waarop die res van die betoog gebou word. Dit open die weg om die teks te gebruik om die opponente en hulle 'dwaalleer' te bepaal. Hierdie veronderstelling en die metode wat daarmee saamgaan, word nie deur Du Toit bevraagteken nie omdat dit baie algemeen aanvaar word in die navorsing oor Paulus se opponente.

Ek wil twee aspekte van dié logika as 'n grondige basis om die opponenteprobleem te hanteer, betwyfel. Die eerste het te doen met die aanname dat die antiteses op 'n polemiek dui en dan meer spesifiek as 'n polemiek oor, of 'n antwoord op beskuldiginge of aanklagte van opponente. Die tweede handel oor die metode van mirror reading wat gebruik word om die opponente en hulle teologiese standpunte te identifiseer.

\subsection{Antiteses - polemiek?}

Dit is ' $n$ vraag of die antiteses enigsins geïnterpreteer moet word as polemies van aard. Soos ek sal aandui nadat die tweede aspek ook ter sprake gekom het, is dit 
waarskynlik noodsaaklik in Du Toit se argument dat dit wel as 'n polemiek beskou word, anders is dit onmoontlik om die opponente of hulle teologiese standpunt te identifiseer.

Abraham Malherbe (1970; kyk ook 1983: 22-28) het die verskynsel van sulke antiteses in kontemporère geskrifte met Paulus nagevors met die doel om die funksie daarvan te bepaal. Hy konsentreer net op die vraag of die antiteses in 1 Tessalonisense 2 as 'n apologie van Paulus in 'n konkrete situasie beskou moet word of nie. Aangesien 'public speakers were viewed with suspicion' (Malherbe 1970: 204) in die eerste-eeuse Grieks-Romeinse wèreld, was dit vir 'n ware filosoof noodsaaklik om homself te onderskei van ander tipes filosowe sonder dat hy direk beskuldig is dat hy ook tot die tipe behoort (kyk Malherbe 1970: 204-205). Hy gebruik die voorbeeld van Dio Chrisostomus wat in die openbaar moes optree en van die gehoor se suspisies teen hom bewus was. Hy het van antiteses gebruik gemaak sonder dat hy nodig gehad het om homself te verdedig 'against specific charges that he was a charlatan' (Malherbe 1970: 205). Malherbe wat duidelike ooreenkomste tussen Dio Chrisostomus en Paulus in 1 Tessalonisense 2 vind, konkludeer: 'One is not obliged to suppose that Dio was responding to specific statements that had been made about him personally', en oor Paulus in 1 Tessalonisense: 'We cannot determine from his description that he is making a personal apology' (Malherbe 1970: 217).

Malherbe se ondersoek het ander navorsers gestimuleer om die antitetiese konstruksies in ander briewe van Paulus na te vors. So het Lyons gekonsentreer op die antitetiese konstruksies in veral die brief aan die Galasiërs en die eerste brief aan die Tessalonisense. Sy gevolgtrekking is dat die antitetiese formuleringe "both inside and outside autobiographical settings are often, if not always, examples of pleonastic tautology used in the interest of clarity which need not be assumed to reply to charges' (Lyons 1985: 110). Dat 'the denials are epexegetical not polemical in purpose' (Lyons 1985: 112), word verder bevestig deur die feit dat sommige van die antitetiese stellings nie gesien word as antwoorde op aanklagtes nie. Dit is byvoorbeeld onvoorstelbaar dat Du Toit, wat talle aanklagtes in Rom 4: 13-25 identifiseer, Rom 4: 20 sal gebruik om te sê dat die klag iets was soos: 'Abraham het in ongeloof begin twyfel' of byvoorbeeld dat die klag in 1 Kor 10: 13 was dat God die mens bo sy vermoë versoek. Die vraag ontstaan op watter gronde besluit word dat sommige antiteses antwoorde op aanklagtes is en ander nie; veral in die lig van die ongeveer 78 antiteses wat Schneider (kyk 1970: 62) in die Romeinebrief alleen identifiseer. Genoeg om te sê dat hierdie probleem in die navorsing oor Paulus se opponente problematies is omdat dit beteken dat byna elke navorser sy eie aanklagtes uit die sogenaamde polemiek konstrueer. 
Die navorsing van Malherbe en Lyons het aangetoon dat die antiteses in die outobiografiese gedeeltes in Galasiërs (en 1 Tess 2) eerder gaan om 'counterpersuasion and dissuasion' (Lyons 1985: 173) as om apologie of polemiek. Du Toit (1988: 73) aanvaar polemiek vir beide Romeine en Galasiërs. Die navorsing van Malherbe en Lyons wek egter heelwat twyfel oor die polemiese funksie van die antiteses in onder andere die Romeinebrief. Die feit dat daar ' $n$ aantal antiteses in Rom 4: 13-25 voorkom, is die enigste rede wat Du Toit anvoer dat dit as 'n polemiek beskou moet word. Die antiteses kon egter heel waarskynlik ' $n$ ander funksie gehad het. In terme van die alternatiewe metode wat ek aan die einde wil voorstel, sal dit blyk dat die antiteses nóg polemies of apologeties, nóg verdediging teen suspisie of epeksegeties hoef gelees te word. Dit kan ook verstaan word binne 'n situasie waar die funksie die skepping van 'n 'symbolic universe' of die legitimering van 'n groep se bestaan was. In so 'n geval sou dit eerder die funksie van oorreding gehad het.

\subsection{Die metode om die opponente en hulle standpunt te bepaal}

Die tweede aspek wat handel oor die metode wat Du Toit gebruik om die opponente te identifiseer, en daarna hulle teologiese standpunt te konstrueer, is sonder veel moeite herkenbaar; veral as gevolg van die noue verband tussen die metode en die voorafgaande aspek oor die polemiek. Sy argument (kyk Du Toit 1988: 74) sien ongeveer soos volg daar uit: Nadat (vas)gestel is dat dit 'n polemiek is, is die identifisering van die opponente 'n blote formaliteit. In Rom 4, soos in Rom 2: 1-2,

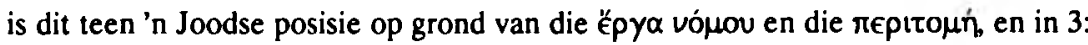
8 (op grond van die tives), 3: 31 en 4:1-2 is dit (ook) teen Joodse Christene. In die polemiek met die fiktiewe Joodse gespreksgenoot onderskei Paulus die geloofsgeregtigheid van die Joodse posisie, en is dit dan tegelyk 'n ontwapening van die Joodse Christen omdat hulle, volgens Du Toit, ten opsigte van soteriologie op 'n beslissende punt ooreenstem. Ek sal net op die metode van mirror reading wat hier gebruik word, konsentreer.

Mirror reading word algemeen aanvaar as metode om Paulus se opponente te identifiseer. Die metode berus op die veronderstelling dat dit wat Paulus sê, deur sy opponente ontken word, en dit wat hy ontken, eintlik hulle standpunt is (vgl Lyons 1985: 81). Die argument loop ongeveer soos volg: Die duidelike antiteses in sy briewe vereis dat hulle as apologetiese briewe (polemies) gelees moet word. Indien dit so is, dan moet dit ipso facto verstaan word in terme van Paulus se antwoorde op sekere aanklagtes en beskuldiginge wat nie eksplisiet gestel word nie. As Paulus se verdediging gelees word, kan die klagtes en beskuldiginge afgelei word uit die negatief van die ontkennings (vgl Tyson 1968: 243-244; Lyons 1985: 80; Barclay 
1987: 73-74). Dit lyk of dit dieselfde metode is wat Du Toit gebruik om die opponente en hulle teologiese standpunt te identifiseer.

Ten spyte daarvan dat die metode baie algemeen gebruik word in die navorsing, is dit nie moontlik om hier volledig in te gaan op al die probleme daarmee nie (kyk veral Lyons 1985: 96-105 en Barclay 1987: 74-79). Een van die prinsipiële besware kom van Betz (1979: 39): 'This method of reconstructing the charge is, however questionable', en '[N]ot every rhetorical denial is an accusation turned around' (Betz 1979: $56 \mathrm{n}$ 115). Betz se voortgaande gebruik van die metode toon egter dat daar geen kriteria is waarvolgens bepaal kan word watter opmerkinge as antwoorde op aanklagtes gesien moet word en watter nie. Howard (1979: 8-9) se beswaar teen die metode is juis op grond van die magdom uiteenlopende klagtes van die opponente wat deur verskillende navorsers uit dieselfde sogenaamde antwoorde afgelei word.

Myns insiens moet met Lyons (1985: 104) saamgestem word dat die veronderstellinge onderliggend aan die metode van mirror reading, bevraagteken behoort te word. Mirror reading, wat veronderstel dat Paulus reageer op aanklagtes van opponente, bevestig juis dit wat veronderstel word, naamlik dat Paulus apologeties of polemies reageer teen opponente se beskuldiginge. Deur 'n apologie of polemiek te veronderstel, kan die opponente en hul aanklagtes geïdentifiseer word. Deur te veronderstel dat Paulus antwoorde gee op klagtes, word bewys dat dit 'n apologie of polemiek is. 'n Verdere probleem met dié metode, wat later weer aan die orde sal kom, is die geskiedenisfilosofiese veronderstelling dat die konflik in die eerste eeu, soos in Paulus se briewe gereflekteer, uitsluitlik 'n history of ideas probleem was. Die teks word met ander woorde as die neerslag van 'n suiwer teologiese konflik tussen Paulus en Jode of Joodse Christene gesien.

Dit behoort reeds duidelik te wees waarom hierdie aspekte so belangrik is. Die res van Du Toit se argument staan of val daarby dat die opponente uit Paulus se teks van Romeine 3 en 4 geïdentifiseer kan word. Uit my redenering blyk dit onwenslik te wees om die teks op hierdie wyse te hanteer. Dit is alles behalwe 'n uitgemaakte saak dat dit 'n polemiek is, en selfs al kan 'n beter saak daarvoor uitgemaak word, kan die metode van mirror reading om genoemde redes nie aanvaar word nie. Is dit nie 'n geval dat die resultaat en die belangrikheid daarvan, die veronderstellinge sowel as die metode vooraf bepaal het nie?

In die lig van bogenoemde redenering is dit, myns insiens, uiters problematies om die opponente of hulle teologiese posisie te identifiseer. Dit is nie eens seker of hier enigsins van opponente sprake is in die sin wat Du Toit redeneer nie. Vir Gaston, wat deur Du Toit aangehaal word, is dit ' $n$ belangrike uitgangspunt dat 'if it is possible to interpret Paul in continuity with the tradition before him, why should 
we not do so' (Gaston 1980: 59). In hierdie lig sê hy dat daar nie opponente veronderstel moet word teen wie Paulus polemiseer, indien Paulus self geen spesifieke aanduiding van hulle gee nie (Gaston 1980: 59). Die punt wat hy wil maak, is dat daar by die identifisering van opponente van wie ons niks weet nie, en na wie Paulus dalk baie indirek verwys, versigtiger met die teks omgegaan moet word. Hierdie uitgangspunt moet gehandhaaf word.

Enkele ander sake, veral ten opsigte van Sanders se metodologie, is in die hele debat van groot belang. Dit is juis wat metodologie betref, dat Du Toit met Sanders in gesprek tree. Dit sal vervolgens bespreek word. Van belang is dat hierdie deel van Du Toit se artikel op die (problematiese) eerste deel gebou is waar die identiteit van die opponente en hulle soteriologie aan die hand van Romeine 4 gekonstrueer is. Hierdie feit lei tot die fundamentele verskille tussen die twee outeurs en laat Du Toit se kritiek oop vir ernstige vrae.

\section{HOOFLYNE VAN DIE SANDERS DEBAT}

In die debat het Du Toit (dié) twee belangrike aspekte van Sanders se bydrae wat van deurslaggewende belang in die voortgaande gesprek is, bevraagteken. Dit het te doen met hermeneutiese en metodologiese uitgangspunte wat dikwels op 'n onderliggende vlak funksioneer.

Du Toit noem agt verskillende opsies in die Paulusnavorsing wat deur Sanders se diskussie na vore gekom het. Ek noem net die laaste vier wat direk van toepassing is op die debat met Sanders:

5. Die traditionelle Exegese hat Paulus irgendwie missverstanden ...

6. Die herkömmliche Forschung hat das palästinische Judentum missverstanden...

7. Sanders hat Paulus nicht ganz richtig verstanden...

8. Sanders hat das palästinische Judentum in toto oder teilweise nicht richtig interpretiert ... (Du Toit 1988: 72).

Die twee groot punte wat Sanders gestel het, is eerstens dat die tradisionele NuweTestamentiese navorsing Palestynse Judaïsme verkeerd verstaan het (stelling 6), en tweedens dat op grond daarvan Paulus ook verkeerd gelees is (stelling 5). Sanders se kritici (waarvan Du Toit een is) het aangevoer dat Sanders vir Paulus nie reg verstaan nie (stelling 7) en verder dat hy Palestynse Judaïsme nie korrek weergegee het nie (stelling 8). Stellings 5 en 7 in Du Toit se argument is keersye van mekaar, en soos Du Toit (1988: 76) self opmerk, hoort stellings 6 en 8 saaklik saam. 
Sanders se twee punte moet duidelik van mekaar onderskei word, maar tog moet die interafhanklikheid daarvan nie misken word nie. Die tradisionele beeld van Palestynse Judaïsme waarteen Sanders dit in stelling 6 het, het alle vraagstukke in die Paulusnavorsing so oorheers dat weinig vrae nie in terme daarvan beantwoord is nie. As hierdie beeld van Palestynse Judaïsme bevraagteken word, dan ook die Paulusinterpretasie wat daarmee saamgegaan het. Dienooreenkomstig sal die kritiek teen Sanders die twee aspekte moet onderskei, maar ook die interafhanklikheid daarvan moet raaksien.

Vervolgens sal ek Sanders se standpunt kortliks weergee omdat dit nie in $\mathrm{Du}$ Toit se artikel volledig bespreek is nie, maar veral omdat dit die beste wyse is hoe sy onderliggende uitgangspunte gedemonstreer kan word. Daarna sal Du Toit se kritiek bespreek word - ook met die klem op die onderliggende uitgangspunte.

\subsection{Sanders se Paulusinterpretasie}

Sanders se logika is duidelik in sy aanbieding herkenbaar. Paulus se briewe moet nie gelees word teen die agtergrond van 'n legalistiese siening van Palestynse Judaïsme nie. Om die rede bevraagteken hy eerstens die tradisionele beeld van Palestynse Judaïsme wat algemeen in Nuwe-Testamentiese navorsing aanvaar word. Die Joodse bronne self spreek volgens Sanders se ondersoek teen so 'n legalisme. Sanders se volgorde is van belang: eers die afwys van 'n dominerende persepsie van Palestynse Judaïsme in die navorsing, dan 'n ondersoek na die Joodse bronne self, en laastens 'n ondersoek van Paulus se briewe onafhanklik van dié tradisionele Protestantse persepsie van Palestynse Judaïsme. Laasgenoemde impliseer dat Sanders sekere hermeneutiese uitgangspunte eksplisiet uitspel; uitgangspunte wat verskil van die tradisioneel aanvaarde uitgangspunte.

\subsubsection{Sanders se kritiek teen 'n sekere beeld van Palestynse Judaisme}

Sanders sluit by die kritiek van G F Moore aan teen 'n baie lang tradisie oor die siening van Rabbynse Judaïsme in die Nuwe-Testamentiese navorsing. Volgens Moore (1921: 229) het Weber, deur gebruik te maak van 'n sisteem van 'Christian dogmatics', dit reggekry om 'n interpretasietradisie te vestig wat versterk is deur onder andere Emil Schürer en Wilhelm Bousset en wat omtrent algemene aanvaarding in Nuwe-Testamentiese navorsing gekry het. Dié tradisie beskou Palestynse Judaïsme as 'n legalistiese godsdiens en daarom is daar 'n fundamentele antitese tussen Judaisme en Christendom (kyk Sanders 1977: 33). Moore (1921: 197) het reeds vroeg in hierdie eeu gewaarsku dat 'Christian interest in Jewish literature has always been apologetic or polemic rather than historical'. Volgens hom is Weber se klem op legalisme nie die gevolg van 'n nuwe en indringende studie van Judaïsme in 
die eerste eeu nie, maar die gevolg van 'a new apologetic motive, consequent on a different apprehension of Christianity' (Moore 1921: 253). Vir Barth (1968: 85) is anti-Semitisme duidelik waar 'the study of Jewish literature is done with the purpose of creating nothing better than a black background against which the light of the New Testament may shine all the brighter'.

Sanders se kritiek teen die Weber/Schürer/Bousset-tradisie is veel sterker as dié van Moore waarop hy bou. Sy probleem is veral dat die beskrywing van eersteeeuse Judaïsme in Christelike kringe as legalisme, 'has a pejorative connotation' (Sanders 1982: 393). Die kern van sy beswaar is in ' $n$ uitstekende samevatting van sy aanvanklike kritiek (kyk Sanders 1977: 33-59) duidelik: 'These negative connotations of the word legalism are no more than theological judgements of Christianity against Judaism. They appear in supposedly scholarly historical works describing Judaism ... but they cannot be found by a study of Jewish literature itself (Sanders 1982: 393-394).

Volgens hierdie 'legalistic works-righteousness'-siening is Judaïsme 'a religion of hypocritical and self-justifying casuistry' (Sanders 1982: 393) waar die wet 'n middel is om God se genade deur goeie werke te verdien. Met ander woorde, 'God saves or damns according to whether or not the individual has more "merits" than "demerits"' (Sanders 1982: 398). Paulus sou teen so 'n godsdiens waar verlossing verdien word, met die leer van verlossing uit genade gereageer het; geregtigheid deur werke teenoor geregtigheid deur die geloof (kyk Sanders 1977: 42-43; Räisänen 1980: 63-64; Dunn 1983: 98 en Barclay 1986: 5).

\subsection{Verbondsnomisme}

Sanders (1977: xii) het dit as mikpunt gestel 'to destroy the view of Rabbinic Judaism which is still prevalent in much, perhaps most, New Testament scholarship'. Hy doen dit deur gebruik te maak van ' $n$ metode waar hy ' $n$ 'pattern of religion' probeer vasstel in die belangrikste Joodse dokumente vanaf $200 \mathrm{vC}$ tot ongeveer 200 nC. Dit stel hom in staat 'to compare a properly described whole with a properly described whole' (Sanders 1973: 456). 'From a massive treatment of most of the relevant Jewish literature for that period' kom Sanders volgens Dunn tot 'a rather different picture' van Palestynse Judaisme (Dunn 1983: 99). Dit is veral uit die Tannaïtiese literatuur (Rabbynse geskrifte) waar die 'pattern' kom. Dit word vir Sanders egter bevestig in die Dooie See geskrifte, asook in die Apokriewe en Pseudepigrafiese literatuur. Een uitsondering is IV Esra wat wel 'n patroon van werke geregtigheid het (kyk Sanders 1976: 41-42).

Sanders noem hierdie 'pattern' wat veral uit die Tannaïtiese literatuur kom, 'covenantal nomism' (1977: 236). 'Briefly put, covenantal nomism is the view that 
one's place in God's plan is established on the basis of the covenant, and that the covenant requires as the proper response of man his obedience to its commandments, while providing means of atonement for transgression' (Sanders 1977: 75; vir 'n omvattender omskrywing van verbondsnomisme vergelyk sy talle werke waarin hy dit duidelik uitspel - 1973: 460-462; 1977: 235-236; 1976: 39-42).

\subsection{Resepsie van Sanders se teses in die navorsingsgemeenskap}

Instemming met Sanders se kritiek en interpretasie, van beide Joodse en Christelike kant, is veelvuldig. Dit sluit in instemming met sy kritiek teen beide 'n sekere Nuwe-Testamentiese persepsie van Palestynse Judaisme asook met sy eie konstruksie van ' $n$ alternatiewe beeld van Palestynse Judaïsme. Dit sal egter blyk dat ten opsigte van die laaste aspek daar nog ernstige probleme is (probleme wat ook teen Du Toit se kritiek van Sanders ingaan).

213.1 Instemming met kritiek teen 'n Nuwe-Testamentiese beeld van Judaisme

Dit is duidelik dat daar redelik wye steun vir Sanders se kritiek teen die Weber/ Schürer/Bousset tradisie bestaan. 'Sanders's attack on Billerbeck is precise and elegant' (Neusner 1978: 189), is 'n stelling waarmee Vermes (1983: 62-66) sekerlik sal saamstem in die lig van sy eie besware teen onder andere Billerbeck en veral Kittel en wat deur ' $n$ ander Joodse geleerde, Sandmel (1978: 158; kyk Neusner 1978: 190), bevestig word. Dat daar 'n redelik algemene aanvaarding van Sanders se kritiek onder Nuwe-Testamentici is, blyk duidelik uit 'n oorsig oor die Sandersdebat (sien bv Beker 1978: 108; Dahl 1978: 154; Porter 1978: 263; Saldarini 1979: 299; Gaventa 1980: 42; Cooper 1982: 124-125; Gaston 1982: 401; Dunn 1983: 102103; Gager 1983: 203; Loader 1984: 11-12; Räisänen 1985: 544 en Moo 1986: 288). Caird (1978: 539) som die konsensus goed op deur te sê: 'For this main thesis, destructive and constructive, Sanders has a strong case'.

\subsubsection{Instemming met Sanders se beeld van Palestynse Judaïsme}

Aansluitend by voorafgaande, is daar ook instemming met Sanders se konstruktiewe aspek. Die instemming op hierdie punt is veel meer gereserveerd, veral as gevolg van die talle besware wat steeds teen Sanders en selfs Moore se standpunte ingebring is. Sanders (1973: 456) se uitgangspunt om Palestynse Judaïsme as 'a properly described whole' te verstaan, vrywaar hom daarvan dat hy die superioriteit van Paulus oor Palestynse Judaïsme wil verdedig; ten minste poog hy om reg te laat geskied aan die Joodse bronne deur hulle in their own terms, te bestudeer (kyk veral Räisänen 1980: 66). Hoe suksesvol hy daarmee was, word bevraagteken. 
Met sy metode vind Neusner talle probleme en tekortkominige. Het Sanders werklik sy bronne gerespekteer deur hulle 'inner structure, heart, and center' (Neusner 1978: 182) te analiseer? Is dit nie ook waar dat Sanders met 'questions of Pauline-Lutheran theology' werk wat beteken dat 'we find ourselves on the peripheries of Mishnaic literature and its chief foci' (Neusner 1978: 181), waar Judaïsme, in al sy literêre bronne, hanteer word 'as monolithic and homogeneous ... within categories of Protestant dogmatic theology' (Neusner 1984: 417-418; kyk Saldarini 1979: 300) nie? Neusner se derde beswaar sny seker die diepste. Dit het te doen met die aard en hantering van Rabbynse bronne deur veral Nuwe-Testamentiese navorsers (en ook deur Sanders). Kortliks kom dit neer op wat hy beskryf as 'a fundamentalistic and childish hermeneutical framework' (Neusner 1978: 189) waar die Rabbynse bronne hanteer word 'in ways in which it would not imagine dealing with New Testament ones' (Neusner 1984: 421). Soos hy tereg opmerk, is dit baie vreemd dat 'Gospel scholars should fall into this trap' (Neusner 1984: 421).

Omdat hierdie laaste punt van kritiek belangrike implikasies vir die voortgaande debat het, wil ek die essensie daarvan kortliks noem. Op watter basis kan dokumente as bronne gebruik word vir dit waarna dit verwys; honderd tot soveel as 'n duisend jaar vroeër? Indien die dokumente oor so 'n lang tydperk tot stand gekom het, hoe kan ons dit hanteer 'as essentially homogeneous and representative of a single "Judaism" and assign that "Judaism" to the 1st century and to the Land of Israel'? Hoe weet ons dat die dokumente 'represent a broad range of national belief, practice, and opinion, which we impute to Jewry' (Neusner 1984: 420-421)? Veral die werk van Neusner het Gaventa oortuig dat dit op hierdie stadium nog nie moontlik is om die 'pattern of religion' van Palestynse Judaisme te beskryf soos wat Sanders probeer doen het nie (sien Gaventa 1980: 39-43). Veel meer studie van die Joodse bronne is nodig om dit werklik in their own terms te verstaan.

Uit Sanders se reaksie op Neusner en andere se kritiek, blyk dat hy bewus is van talle van die besware wat teen sy standpunt genoem word. Hy sou wou sien dat sy eie metode ernstig beoordeel word 'in terms of my intentions and less in the light of their own programs of how the material should be studied' (Sanders 1980: 75). Die debat tussen Sanders en Neusner gaan op dié punt steeds voort.

Deur die kritiek teen Sanders toe te gee, beteken nie dat die tradisionele beeld van Palestynse Judaïsme steeds aanvaar moet word nie. Dit is die rede waarom talle navorsers wat Sanders kritiseer ten opsigte van sy metode, dit honderd persent eens is met sy kritiek teen die bevooroordeelde persepsie van Judaisme wat gangbaar is in Nuwe Testamentiese navorsing. Hoewel Sanders volgens die oordeel van vakgenote nog nie sy program suksesvol uitgevoer het nie, bied dit metodologies 'n beter alternatief as dit wat hy gekritiseer het. 
Ten spyte van sy kritiek is Neusner (1978: 180) se oordeel oor Sanders se verbondsnomisme veelseggend: 'So far as Sanders proposes to demonstrate the importance to all the kinds of ancient Judaism of covenantal nomism, election, atonement, and the like, his work must be pronounced a complete success'. Dit is veral belangrik in die lig van Neusner se eie studie van talle van die Joodse bronne wat al neerslag gevind het in ten minste 83 publikasies (kyk Neusner 1983: 6).

\subsubsection{Sanders se hermeneutiese uitgangspunte}

Daar kan min twyfel wees dat Sanders se hele program ook neerkom op 'n kritiek van die tradisionele verstaan van Paulus: 'Sanders's work is the first deliberately systematic confrontation with the classical Protestant interpretation of Paul, especially as expressed in German scholarship' (Davies 1984: $330 \mathrm{n}$ 9). Dit is inteendeel een van die oogmerke met sy studie 'to argue for a certain understanding of Paul' (Sanders 1977: xii) of soos Barclay (1986: 7) opmerk: Sanders se werk is die mees belangrike een 'in challenging standard interpretations of Paul'. Dunn (1983: 100) sê dat 'Stendahl cracked the mould of 20th century reconstructions of Paul's theological context' en 'Sanders has broken it altogether by showing how different these reconstructions are from what we know of first-century Judaism from other sources'.

Wat Davies hier die klassieke Protestantse interpretasie van Paulus noem (Watson 1986: 2-10 beskryf dit as die 'Lutheran approach'), het hand aan hand gegaan met die Schürer/Weber/Bousset tradisie van Palestynse Judaïsme. Dit het onder andere sekere veronderstellinge oor die aard van Paulus se briewe ingesluit, die rede vir sy skrywe daarvan en regverdiging deur die geloof as die sentrum van Paulus se teologie. Watson (1986: 18) is van mening dat die proses van 'delutheranizing Paul' reeds ver gevorder het, en Sanders se werk het deel daaraan om die onbehae met die Lutherse benadering tot Paulus uit te lig. Hierdie onbehae beteken dat talle van die algemeen aanvaarde uitgangspunte en resultate van die tradisionele interpretasie ernstig bevraagteken en selfs verwerp is.

Die bevraagtekening van die tradisionele beeld van Palestynse Judaïsme in die navorsing en die stel van 'n alternatief daarop wat reeds bespreek is, is sekerlik Sanders se belangrikste uitgangspunt. Dit is teen hierdie agtergrond dat Gaston (1980: 59) opmerk: 'Every interpretation of Paul that is based on a misrepresentation of Judaism is to be rigorously excluded'. Om met Watson (1986: 180) se oordeel saam te stem: 'Whatever its theological merits, the Reformation tradition has no right to regard itself as the guardian of authentic Pauline teaching, since its theological concerns have hindered rather than helped a correct understanding of the apostle'. Uit hierdie twee reaksies blyk duidelik die effek van sekere herme- 
neutiese uitgangspunte, en veral die effek van 'n bepaalde siening van Palestynse Judaïsme, op die konstruksie van Paulus se teologiese konteks. Sanders self het probeer aantoon hoe dit die interpretasie van Paulus se briewe raak indien Palestynse Judaïsme anders lyk as die tradisionele.

'n Volgende uitgangspunt wat Sanders deel (kyk Sanders 1977: 441-442; 1978: 177-178; 1983: 17-22), is dat Paulus se briewe gerig is aan 'gentile Christians, dealing with gentile-Christian problems' (Gaston 1979: 56). Verlossing is beskikbaar vir Jood en heiden op dieselfde basis, naamlik geloof in Jesus, en Paulus is geroep as apostel om dit te verkondig (kyk Sanders 1983: 5). Veral Gaston (1979: 56-62) en Stendahl (1976: 1-77) het gewys op die invloed van hierdie uitgangspunt en Sanders se latere werk (1983) toon die effek daarvan op die praktiese interpretasie van die Paulusbriewe. Aansluitend hierby is die feit dat Sanders, soos talle ander navorsers vandag, onder andere Davies en Stendahl (kyk Sanders 1978: 175), nie meer aanvaar dat regverdiging deur die geloof die sentrum en beginpunt van Paulus se teologie is nie (kyk Sanders 1977: 434-442; 482-495).

Sanders se interpretasie van Rom 4 dien as voorbeeld hoe bogenoemde uitgangspunte sy lees van die tekste bepaal. Paulus se sentrale vraagstuk hier is die 'equal standing of Jew and Gentile' (Sanders 1983: 30). Binne die raamwerk dui kouxâoal in Rom 2: 17 en 23 op 'the assumption of special status on the part of the Jews' (Sanders 1983: 33), en daarom ook in Rom 3: 27 (kyk ook Räisänen 1980: 7071). Op grond daarvan konkludeer Sanders (1983: 33): 'The argument ... is in favor of equal status and against privilege - especially against boasting in privileged status'. Die voorbeeld van Abraham in Rom 4 moet hierdie punt bevestig. Sanders

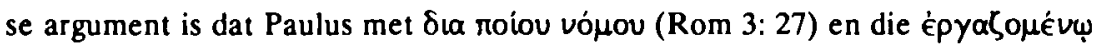
(Rom 4: 4), nie ' $n$ verdiensteleer aanval nie. Volgens hom is dit duidelik dat die ander terme ("Jews" 3: 29; "the circumcision" 3:30; 4: 9, 12; those "of the law" 4:14, 16') wat Paulus gebruik om diegene wat hy kritiseer te beskryf, is 'all phrases which focus on status, not religious attitude or behavior' (Sanders 1983: 34). Hieruit konkludeer Sanders dat Paulus se gebruik van nie deur die werke van die wet 'is not against a supposed Jewish position that enough good works earn righteousness', maar is gerig teen die standaard Joodse siening 'that accepting and living by the law is a sign and condition of favored status' (Sanders 1983: 46). Paulus kritiseer met ander woorde die tradisionele verstaan van 'non-Christian Judaism' daarin dat hy 'the notion of Jewish privilege and the idea of election' (Sanders 1983: 47) aanval. Sanders bevestig daarmee sy siening dat Paulus in wese die Judaïsme van sy tyd verwerp het: 'What is wrong with the law, and thus with Judaism, is that it does not provide for God's ultimate purpose, that of saving the entire world through faith in Christ, and without the privilege accorded to Jews through the promises, the 
covenants, and the law' (Sanders 1983: 47).

Hoewel daar baie ooreenkomste tussen Sanders en Räisänen is, dink ek Sanders maak ' $n$ fout as hy reken dat hulle ooreenstem op die punt dat daar geen teken van 'n selfreguerdigingsleer op grond van werke deurskemer in Paulus se kritiek nie (kyk Sanders 1983: 59 n 88). Räisänen (1980: 64-65), wat 'n onderskeid tussen harde en sagıe legalisme maak, sê: 'Paul's attack on the Jewish way is based on a vision of it as "soft" legalism' (1980: 71). Dit is egter nie die basiese fout met die Jode nie, maar wel die feit dat hulle nie besef het die nuwe era het met Jesus aangebreek nie (kyk Räisänen 1980: 71). Die rede vir hierdie stukkie kritiek teen Sanders se interpretasie van Rom 4 sal aan die einde duidelik word waar ek 'n alternatief op beide Sanders en Du Toit se interpretasies voorstel.

Die gaping tussen die tradisionele Protestantse interpretasie en diegene wat dit bevraagteken, is duidelik (kyk Moo 1986: 292-293). Sekere fundamentele keuses het 'n effek op die interpretasie van omtrent elke aspek van Paulus se briewe. Ek dink dat een van die redes vir die verskil tussen Sanders en Du Toit op hierdie vlak lê. Daarom het Sanders se teses soveel aandag gekry; dit is 'n poging om hierdie verskille en die redes daarvoor uit te lig.

Om Sanders se Paulusinterpretasie saam te vat en af te sluit: Hierdie was 'n poging om agter die logika van stellings 5 en 6 in te kom. Sanders beklemtoon eerstens die prioriteit en belang om die Joodse bronne self te lees. Kritiek teen sy Paulusinterpretasie kan baie moeilik anders as om sy kritiek teen die Schürer/ Weber/Bousset skema of af te wys of te aanvaar. Dit beteken egter nie dat sy eie konstruksie van Palestynse Judaïsme aanvaar moet word nie, maar dit het heelwat meriete. Tweedens sal sy tese oor die invloed van die tradisionele Protestantse interpretasietradisie op die lees van Paulus se briewe aan die orde moet kom. Ook hier hoef nie met sy eie konstruksie saamgestem te word om sy kritiek teen sekere tradisionele hermeneutiese uitgangspunte te aanvaar nie. Dit is belangrik dat indien uitgangspunte afgewys of aanvaar word, dit gedoen moet word met die besef dat uitgangspunte nou verweef is aan sekere interpretasietradisies.

\subsection{Sanders het Paulus en Palestynse Judaïsme misverstaan?}

Du Toit verdedig stellings 7 en 8 wat beide Sanders se Paulusinterpretasie en sy beeld van Palestynse Judaïsme bevraagteken. Die volgorde van sy redenering verraai baie oor sy eie veronderstellinge. Ek sal die verskil in onderliggende struktuur met Sanders probeer aandui en tegelyk Du Toit se kritiek teen Sanders evalueer.

Soos reeds gesien, begin Du Toit met 'n beeld van Joodse soteriologie soos gekonstrueer uit die Romeinebrief. Dit word dan getoets deur voorbeelde uit die 
Joodse geskrifte. Op die basis word Sanders se teses dan bevraagteken.

\subsubsection{Sanders se Paulusinterpretasie bevraagteken}

Vir Du Toit is stelling 5 nie aanvaarbaar nie, want Paulus 'wollte in der Tat eine jüdische Richtung Bekämpfen, deren Soteriologie er als einen nomistischen Irrweg verstand' (1988: 76). Vanselfsprekend is 7 dan korrek, en die motivering: 'Paulus kritisiert ... die Gesetzesgerechtigkeit ... weil sie als solche falsch ist' (Du Toit 1988: 76). Beide hierdie motiverings kom natuurlik uit sy lees van Rom 4 (kyk Du Toit 1988: 74), waar soos reeds aangedui, deur middel van mirror reading, Joodse opponente met 'n legalistiese soteriologie gekonstrueer is. Op grond daarvan kom hy tot die konklusie dat Sanders vir Paulus verkeerd verstaan het, en dat Sanders se kritiek teen die tradisionele eksegese daarom verwerp moet word.

Selfs al bevestig 'n ausgedehntes Forschungsprogramm so 'n soteriologie, het ons reeds gesien dat Du Toit se lees van Rom 4 talle probleme het. Belangriker egter is dat daardie lees op 'n subtiele wyse dit veronderstel wat Sanders bevraagteken het, naamlik die bestaan van 'n legalistiese Joodse godsdiens in die eerste eeu. In die verdediging van stelling 7 bou Du Toit op die bestaan van so 'n problematiese beeld van Palestynse Judaïsme. Gesien in die lig van Sanders se kritiek is Moo (1986: 293) reg as hy opmerk dat die tipe oplossing wat Du Toit handhaaf, 'is left hanging in mid-air'. Kan daardie beeld nog onproblematies gehandhaaf word? Dit is veelseggend dat te midde van die kritiek teen Sanders se eie konstruksie van Palestynse Judaïsme, daar geen (sover ek kon vasstel) ernstige beswaar teen sy kritiek van die Weber/Schürer/Bousset tradisie is nie. 'n Opmerking van Du Toit (1988: 78) in die rigting: 'Wird ein Spezialist wie Billerbeck, der 16 Jahre an diesem Material gearbeit hat, sich wirklich so völlig geirrt haben?, is nie baie effektief nie. Sestien jaar se arbeid waarborg blykbaar nie onbevooroordeeldheid soos duidelik blyk uit die kritiek van Moore, Vermes, Sanders en andere nie.

Dit is op hierdie punt dat Du Toit nalaat om met Sanders in gesprek te tree oor eksplisiete vertrekpunte. Du Toit (1988: 74) se opmerking: 'Grundsätzlich polemisiert er mit einem fiktiven jüdischen Gesprächspartner', verskil lynreg met die situasie wat Sanders (1983: 32-36) voorstel, naamlik dat Paulus hier geïnteresseerd is in die status van die heidene. Kan Sanders se interpretasie daarmee afgewys word sonder dat hierdie verskilpunt beredeneer word, want die verskil spruit direk voort uit verskillende vertrekpunte?

\subsubsection{Sanders se Palestynse Judaĩsme getoets}

Du Toit (1988: 79) se opmerkings dat 'n 'umfassende neue Untersuchung der jüdischen Quellen' nodig is, indien stellings 6 en 8 , wat beide handel oor die vraag of 
die Joodse soteriologie wel nomisties was, getoets wil word, sluit aan by die kritiek wat reeds uitgespreek is teen Sanders se konstruksie. In die lig hiervan wil ek vra of dit in beginsel moontlik is om uit die enkele voorbeelde (vier) die vraag te vra of Sanders nie net die materiaal gebruik het wat sy saak pas, en dit uitgelaat het wat teen sy saak getuig nie? (kyk Du Toit 1988: 78 ). Kan enkele voorbeelde selfs suspisie wek oor die beeld van Palestynse Judaïsme wat gekonstrueer is?

Ek vra die vrae veral in die lig van Neusner se kritiek teen die gebruik van die Joodse materiaal deur Nuwe Testamentici en Du Toit (1988: 78) se opmerking oor Sanders: 'Hat Sanders den Kontext und die Eigenart seiner Dokumente genügend beachtet?'. Sou hierdie vier voorbeelde daardie toets deurstaan? Sanders (1977: 71) self merk op: 'Even if we could show that some one Rabbi held a view of religion completely different from that ascribed to the Rabbis by Bousset, Billerbeck and their followers, this would not show that the Bousset/Billerbeck view is wrong'. Dit, tesame met die feit dat Sanders toegee dat sekere tekste wat hy gelees het, wel teen sy patroon van verbondsnomisme getuig, byvoorbeeld IV Esra, dwing my om met Barclay (1986: 8; kyk ook Räisänen 1980: 66) saam te stem dat: 'a major new analysis of first-century Judaism' is nodig 'to overturn Sanders' description of it'. Enkele voorbeelde sou dit beswaarlik kon doen.

Du Toit toets Sanders se konstruksie omdat hy vermoed dat Sanders se tese oor die tradisionele beeld van Rabbynse Judaisme in Nuwe-Testamentiese navorsing by hom gefunksioneer het as hermeneutiese sleutel. Dit sou wetenskaplik verantwoord wees om te vra of die tese nie gelei het tot 'n bevooroordeelde lees van die Joodse bronne nie. Hier mis ek weereens 'n erns met Sanders se kritiek teen die tradisionele beeld van Palestynse Judaïsme. Dit is die een been waarop Sanders staan. Ongeag of die ander been, Sanders se eie konstruksie, geprejudiseer is of nie, Sanders het die tradisionele beeld bevraagteken, maar dit bly steeds Du Toit se norm waarteen hy Sanders se konstruksie meet. Deur dit prontuit te stel: 'n Verwerping van Sanders se konstruksie as geprejudiseer, beteken nie 'n bevestiging dat die tradisionele een korrek is nie.

My opmerking oor die volgorde van Du Toit se argument kry nou meer betekenis. Soos met sy interpretasie van Rom 4, dui sy redenering hier ook daarop dat $\mathrm{Du}$ Toit breedweg gesien, binne die tradisionele Protestantse tradisie van die Paulusinterpretasie staan. Dit het meegebring dat stellings 5 en 7 beredeneer kon word voordat die vraag oor Palestynse Judaisme uit die Joodse bronne ter sprake gekom het. Laasgenoemde is nie in die eerste plek vanuit die Joodse bronne gekonstrueer nie, maar vanuit Rom 4. Stelling 8 word as 'n goeie moontlikheid voorgehou op grond van vier teenvoorbeelde teen Sanders se konstruksie wat lyk asof hulle die prentjie van Rom 4 bevestig. Lei die volgorde van redenering nie noodwendig tot sy 
konklusie nie?

Bogenoemde bespreking handel veel meer oor metodologie en uitgangspunte in die navorsing as oor inhoudelike aspekte van die korrekte Paulusinterpretasie of die korrekte konstruksie van Palestynse Judaïsme in die eerste eeu. Sonder om Sanders se interpretasie toe te gee, het ek probeer aantoon dat Du Toit se kritiek, myns insiens, nie die essensie van Sanders se werk aanspreek nie. Vir die voortgaande debat is dit essensieel dat hierdie verskille duidelik in die oog gehou word.

Ek het gepoog om binne die raamwerk van Sanders, na sy bydrae en Du Toit se kritiek daarop, te kyk. In die laaste afdeling wil ek 'n alternatiewe raamwerk voorstel wat beide Sanders en Du Toit s'n uitdaag tot vernuwing. Soos beloof, sluit dit aan by die geskiedenisfilosofiese probleem wat vroeër geïdentifiseer is.

\section{DIE PAD VORENTOE}

Die waarde van bogenoemde debat lê vir my op twee vlakke: eerstens, is die invloed van 'n onpartydige behandeling van die Joodse godsdiens van die eerste eeu 'n vereiste vir Nuwe-Testamentiese navorsing. Hierdie godsdiens met sy literatuur is per slot van sake, soos Vermes (1983: 71) sê, die 'larger canvas' wat die moontlikheid bied van 'added clarity and fuller meaning' vir Nuwe-Testamentiese navorsing. Tweedens is dit belangrik dat historiese vastepunte en hermeneutiese vertrekpunte uitgespel en beredeneer moet word. Dit geld beide die konstruksie van Judaïsme in die eerste eeu as Paulus se spesifieke situasie.

Op sigself is dit nie voldoende nie, want soos reeds aangedui, gaan bogenoemde debat mank aan die geskiedenisfilosofiese veronderstelling dat hier 'n konflik van idees tussen Paulus en 'n groep opponente is, met ander woorde dit gaan oor kompeterende (Judaïstiese) teologieë in die eerste eeu.

Om die probleem in bogenoemde terme te sien, is meer as net 'n verskraling daarvan. Om met Watson (1986: 20) saam te stem: enige verstaan van Paulus se teologiese refleksie wat nie erns maak met sy sosiale konteks nie, 'misunderstands what the historical Paul was doing and saying'. Dit gaan oor verstaan of misverstaan. Onderliggend aan enige interpretasie van die Paulusbriewe, is daar 'n siening van die sosiale konteks. Ek betwyfel dit dat die konteks van 'n teologiese debat die beste reg laat geskied aan Paulus se briefwisseling. Hier is veel meer aan die gang as bloot die neerslag van verskillende standpunte. Daarom, selfs vir teoloë wat primèr belangstel in die teologiese verskille, is dit onmoontlik om dit alleen maar 'in terms of conflicting theologies' (Neyrey 1988: 97) te hanteer. Hierdie 'veel meer' moet deel word van die debat.

As dit dan nie 'n konflik tussen teologieë is nie, wat is dit dan? Wat Du Toit 
(1988: 73) sê oor die funksie van die antiteses, naamlik: 'Es geht um Selbstdarstellung und Selbstverantwortung ( $\mathrm{AB} d \mathrm{~T}$ ) christlichen Glaubens' en verder sy aanhaling van Moxnes dat dit gaan om 'the creation and preservation of their "symbolic universe" that was at stake' (Du Toit 1988: 73), is myns insiens die rigting wat die navorsing moet beweeg. 'n Ontwikkeling in hierdie rigting bied 'n nuwe uitdaging aan die navorsing, maar open ook die weg om te ontkom aan sommige van die doodloopstraat-situasies wat in die navorsing bestaan. Ek noem kortliks twee voorbeelde om aan te dui wat gedoen kan word.

In Paulus se briewe is daar duidelik tekens te sien van 'an intense sense of rivalry, competition, and even jealousy' (Neyrey 1988: 97). Deur die implikasies van hierdie stelling in ag te neem by die interpretasie van Paulus se woorde, sal aan 'n vraag soos wat Du Toit vra, 'Hat Paulus, der Ex-Pharisäer, sich hinsichtlich der Gesetzgerechtigkeit als entrance requirement geirrt? nuwe moontlikhede bied. Dit het dan nie meer die implikasie dat alles wat Paulus gesê het, feitlik korrek moet wees omdat Paulus tog sou geweet het wat die Jode se teologiese standpunte was nie. Die besondere konteks waarin Paulus besig is met die 'creation and preservation' van 'n nuwe godsdienstige groep se 'symbolic universe' kan as kenmerk hê dat iemand in so 'n situasie, juis nie sy 'opponente' se standpunt objektief sal weergee nie (kyk Berger en Luckmann 1966: 179); dit geld ook vir Paulus. Binne die raamwerk van so 'n situasie sou gekyk kan word na dit wat Paulus doen om die Christene te verseker van hul keuse, hulle skietgoed te gee teen ander groepe, of selfs net gemoedsrus te gee oor die keuse wat hulle gemaak het om tot die (nuwe?) geloof te kom.

'n Tweede voorbeeld is Sanders en Du Toit se interpretasies van Rom 4 wat 'n voorbeeld is van hoe 'n klem op hoofsaaklik die teologiese verskille die navorsing deursuur. Op die vlak is een van die probleme met Du Toit se interpretasie dat indien hy Paulus reg lees, dan beskryf Paulus 'n Judaïsme wat nie bestaan het nie (kyk Räisänen 1980: 71). Aan die ander kant geld Räisänen (1987: 411) se opmerking oor Sanders se teologiese interpretasie, dat as dit korrek is, 'then Paul did not communicate his message too clearly', want 'undoubtedly most readers do get from a long series of passages (of which Romans 4 is the most prominent) the impression that Judaism is based on human efforts as opposed to Paul's new faith'.

Räisänen (1980: 81) konstrueer 'n moontlike situasie van Paulus wat aanleiding kon gee tot die konflik waarin hy, soos dikwels in 'n polemiese situasie kan gebeur, 'came unintentionally to distort his opponents' position'. Dit was naamlik 'n situasie waar 'n 'Jewish-Christian theological restoration, with its practical program, constituted a threat to the existence of Gentile converts and to Paul's Gentile mission' (Räisänen 1980: 81). Hoewel dit grootliks 'n hipotetiese historiese 
rekonstruksie (kyk Räisänen 1980: 82) is, is dit minstens 'n poging om Paulus se uitsprake in 'n sekere konteks te verstaan. Hoewel Räisänen steeds dink in terme van 'n polemiek, is hy bereid om die dinamika wat dikwels deel is van so 'n polemiek, in die spel te plaas wanneer Paulus se woorde geïnterpreteer word. Op hierdie vlak moet die navorsing voortgaan en veral, deur gebruik te maak van ander vakgebiede soos byvoorbeeld die sosiologie of antropologie, die veelvuldige dimensies van die sosiale en ander kontekste in die ondersoek insluit. Om byvoorbeeld Räisänen se konstruksie te gebruik kan dalk meer lig werp op die optrede van Paulus en die moontlike redes daarvoor. Hy merk op: 'Paul writes in a conflict setting. If he, in the heat of the debate, did full justice to the form of life he had surrendered, he would be a singular figure in religious history' (Räisänen 1987: 411).

Hierdie tipe studies open moontlikhede om die teologiese uitsprake en konflikte in 'n totaal nuwe lig te sien. Sowel Du Toit as Sanders wil self nie hulle voet op hierdie pad waag nie, hoewel beide die waarde daarvan erken (kyk Sanders 1982: 393 en Du Toit 1988: 73). Myns insiens kan die navorsing net daarby baat deur hierdie ontwikkeling ernstig op te neem.

\section{Literatuurverwysings}

BARCLAY, JMG 1986. Paul and the law: Observations on some recent debates. Themelios 12, 5-15.

BARCLAY, JMG 1987. Mirror-reading a polemical letter: Galatians as a test case. JSNT 31, 73-93.

BARTH, M 1968. Was Paul an anti-Semite? JES 5, 78-104.

BEKER, JC 1978. Review article of Sanders, EP, Paul and Palestinian Judaism: A comparison of patterns of religion. ThTo 35, 108-111.

BERGER, PL \& LUCKMANN, T 1966. The social construction of reality: A treatise in the sociology of knowledge. New York: Penguin.

BETZ, HD 1979. Galatians: A commentary on Paul's letter to the churches in Galatia. Philadelphia: Fortress.

CAIRD, GB 1978. Review article of Sanders, EP, Paul and Palestinian Judaism: A comparison of patterns of religion. $J T h S 29,538-543$.

COOPER, KT 1982. Paul and Rabbinic soteriology: A review article. WTh 44, 123-139.

DAHL NA 1978. Review article of Sanders, EP, Paul and Palestinian Judaism: A comparison of patterns of religion. Religious Studies Review 4/3, 153-158.

DAVIES, WD 1984. Paul and the law: Reflections on pitfalls in interpretation, in Davies, WD (ed), Jewish and Pauline studies, 91-122, 329-341. Philadelphia: Fortress. 
DEIDUN, T 1986. E P Sanders: An assessment of two recent works: 1. 'Having his cake and eating it': Paul on the law. HeyJ 17, 43-52.

DUNN, JDG 1983. The new perspective on Paul. BJRL 65/2, 95-122.

DUNN, JDG 1985. Works of the law and the curse of the law: Galatians 3: 10-14. NTS 31, 523-542.

DU TOIT, AB 1988. Gesetzesgerechtigkeit und Glaubensrerechtigkeit in Rom 4: 13-25: In Gespräch mit EP Sanders. HTS 44, 71-80.

GAGER, JG 1983. The origins of anti-Semitism: Attitudes towards Judaism in pagan and Christian antiquity. Oxford: Oxford University Press.

GASTON, L 1979. Paul and the Torah, in Davies, AT (ed), Antisemitism and the foundation of Christianity, 48-71. New York: Paulist.

GASTON, L 1980. Abraham and the righteousness of God. Horizons in Biblical Theology 2, 39-68.

GASTON, L 1982. Israel's enemies in Pauline theology. NTS 28, 400-423.

GAVENTA, BR 1980. Comparing Paul and Judaism: Rethinking our methods. BTB 10, 37-44.

GAVENTA, BR 1986. Galatians 1 and 2: Autobiography as paradigm. Nov $T 28 / 4$, 309-326.

GUNDRY, RH 1985. Grace, works, and staying saved in Paul. Bib 66, 1-38.

HORBURY, W 1979. Paul and Judaism. ET 90, 116-118.

HOWARD, GE 1979. Paul: Crisis in Galatia. A study in early Christian theology. Cambridge: Cambridge University Press. (MSSNTS 35.)

LOADER, B 1984. Paul and Judaism: Is he fighting strawmen? Colloquium 16/2, 11-20.

LYONS, G 1985. Pauline autobiography: Towards a new understanding. Atlanta: Scholars Press. (SBL DS 72.)

MALHERBE, AJ 1970. "Gentle as a nurse": The Cynic background to 1 Thes 2. NT 12, 203-217.

MALHERBE, AJ 1983. Social aspects of Early Christianity. Philadelphia: Fortress. MCNAMARA, M 1979. Review article of Sanders, EP, Paul and Palestinian Judaism: A comparison of patterns of religion. JSNT 5, 67-73.

MOO, D 1986. Paul and the law in the last ten years. SVTh 40/2, 287-307.

MOORE, JF 1921. Christian writers on Judaism. HThR 14(3), 197-254.

NEUSNER, J 1978. Comparing Judaisms: Review article: Sanders, EP, Paul and Palestinian Judaism: A comparison of patterns of religion. $H R$ 18, 177-191.

NEUSNER, J 1980. The use of the later Rabbinic evidence for the study of Paul, in Green, W S (ed), Approaches to ancient Judaism, Vol 2, 43-63. Atlanta: Scholars Press. 
NEUSNER, J 1983. Formative Judaism: Religious, historical, and literary studies. (Second series). Chico: Scholars Press.

NEUSNER, J 1984. Sanders' Paul and the Jewish people. JQR 74/4, 416-423.

NEYREY, JH 1988. Bewitched in Galatia: Paul and cultural anthropology. $C B Q$ $50 / 1,72-100$.

PORTER, CL 1978. A new paradigm for reading Romans: Dialogue between Christians and Jews. Encounter 39/3, 257-272.

RäISäNEN, H 1980. Legalism and salvation by the law: Paul's portrayal of the Jewish religion as a historical and theological problem, in Pedersen, $\mathrm{S}$ (Hrsg), Die paulinische Literatur und Theologie, 63-83. Arhus: Forlaget Aros.

RäISäNEN, H 1985. Galatians 2: 16 and Paul's break with Judaism. NTS 31, 543553.

RäISäNEN, H 1987. Paul's conversion and the development of his view of the law. NTS 33, 404-419.

SALDARINI, AJ 1979. Review article of Sanders, EP, Paul and Palestinian Judaism: A comparison of patterns of religion. JBL 98, 299-303.

SANDERS, EP 1973. Patterns of religion in Paul and Rabbinic Judaism: A holistic method of comparison. HThR 66, 455-478.

SANDERS, EP 1976. The covenant as a soteriological category and the nature of salvation in Palestinian and Hellenistic Judaism, in Hamerton-Kelly, R \& Scroggs, R (eds), Jews, Greeks and Christians: Religious cultures in late antiquity, 11-44. Leiden: Brill.

SANDERS, EP 1977. Paul and Palestinian Judaism: $A$ comparison of pattems of religion. London: SCM

SANDERS, EP 1978. Paul's attitude towards the Jewish people. USQR 33 (3-4), 175-187.

SANDERS, EP 1980. Puzzling out Rabbinic Judaism, in Green, WS (ed), Approaches to Ancient Judaism, Vol II, 65-79. Atlanta: Scholars Press. (Brown Judaic Studies 9.)

SANDERS, EP 1982. Jesus, Paul and Judaism. ANRW 25.1, 390-450.

SANDERS, EP 1983. Paul, the law, and the Jewish people. Philadelphia: Fortress.

SANDMEL, S 1978. Review article of Sanders, EP, Paul and Palestinian Judaism: A comparison of patterns of religion. Religious Studies Review 4(3) 158-160.

SCHNEIDER, N 1970. Die rhetorische Eigenart der paulinischen Antithese. Tübingen: Mohr.

SNODGRASS, K 1988. Spheres of influence: A possible solution to the problem of Paul and the law. JSNT 32, 93-113.

STENDAHL, K 1976. Paul among Jews and Gentiles. London: SCM. 
TYSON, JB 1968. Paul's opponents in Galatia. NT 10, 241-254.

VERMES, G 1983. Jewish studies and New Testament interpretation, in Vermes, $\mathrm{G}$ (ed), Jesus and the world of Judaism, 58-73. London: SCM.

WATSON, F 1986. Paul, Judaism and the Gentiles: $A$ sociological approach. Cambridge: Cambridge University Press.

WEDDERBURN, AJM 1985. Paul and the law. STTh 38, 613-622. 